Prepared in cooperation with the Indiana Office of Community and Rural Affairs

\title{
Flood-Inundation Maps for the Tippecanoe River at Winamac, Indiana
}

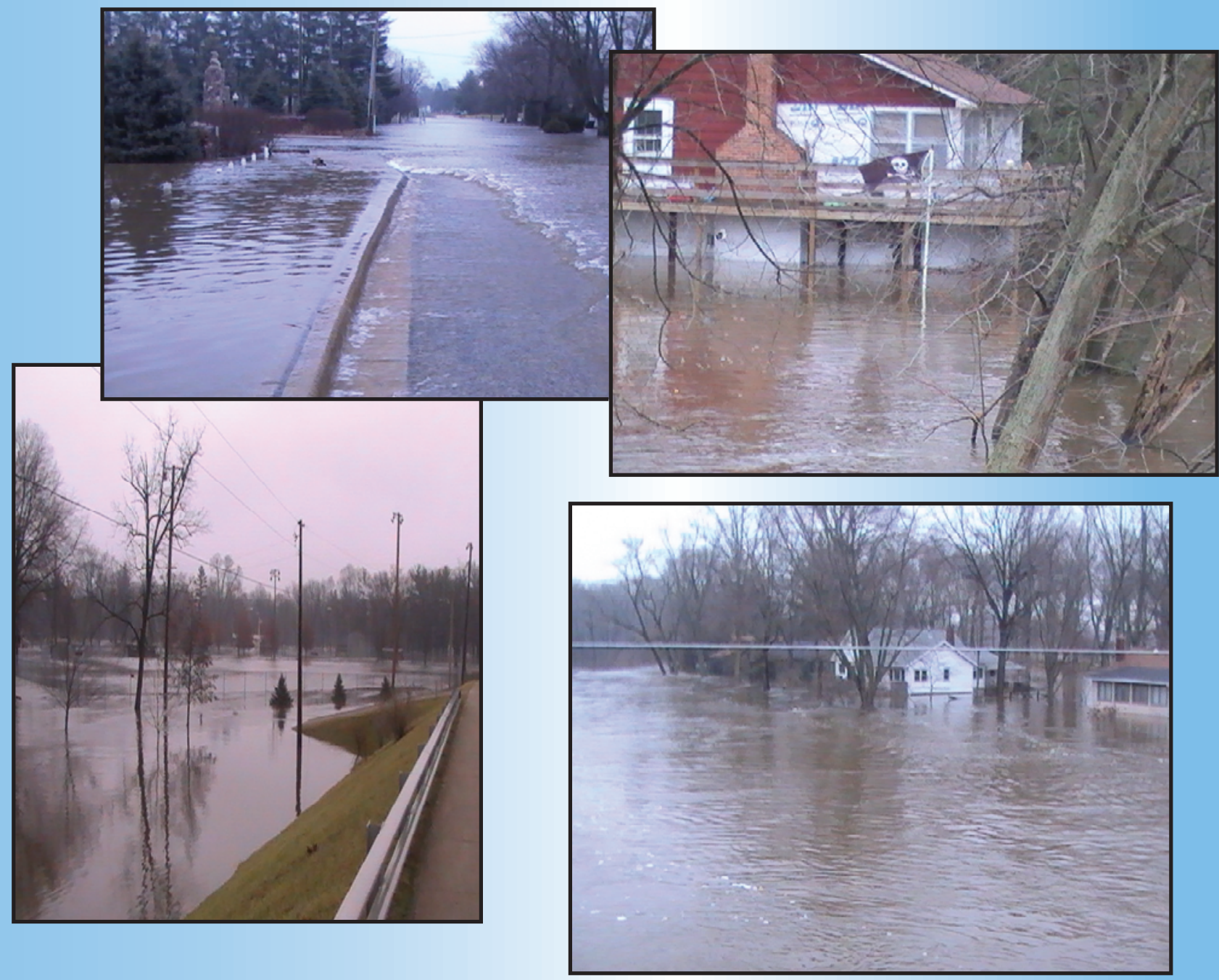

Scientific Investigations Report 2015-5103

U.S. Department of the Interior

U.S. Geological Survey 
Cover: All photographs taken by U.S. Geological Survey hydrologic technician Ron Knapp during a flood measurement made on the Tippecanoe River at Winamac, Indiana, January 2008. 


\section{Flood-Inundation Maps for the Tippecanoe River at Winamac, Indiana}

By Chad D. Menke and Aubrey R. Bunch

Prepared in cooperation with the

Indiana Office of Community and Rural Affairs

Scientific Investigations Report 2015-5103 


\title{
U.S. Department of the Interior SALLY JEWELL, Secretary
}

\section{U.S. Geological Survey \\ Suzette M. Kimball, Acting Director}

\author{
U.S. Geological Survey, Reston, Virginia: 2015
}

For more information on the USGS - the Federal source for science about the Earth, its natural and living resources, natural hazards, and the environment—visit http://www.usgs.gov or call 1-888-ASK-USGS.

For an overview of USGS information products, including maps, imagery, and publications, visit http://www.usgs.gov/pubprod/.

Any use of trade, firm, or product names is for descriptive purposes only and does not imply endorsement by the U.S. Government.

Although this information product, for the most part, is in the public domain, it also may contain copyrighted materials as noted in the text. Permission to reproduce copyrighted items must be secured from the copyright owner.

Suggested citation:

Menke, C.D., and Bunch, A.R., 2015, Flood-inundation maps for the Tippecanoe River at Winamac, Indiana: U.S. Geological Survey Scientific Investigations Report 2015-5103, 9 p., http://dx.doi.org/10.3133/sir20155103.

ISSN 2328-0328 (online) 


\section{Acknowledgments}

The authors wish to thank the many local, State, and Federal agencies that have cooperated in the funding of the operation and maintenance of the streamgages. Special thanks are given to the National Weather Service for their continued support of the U.S. Geological Survey floodinundation mapping program. 



\section{Contents}

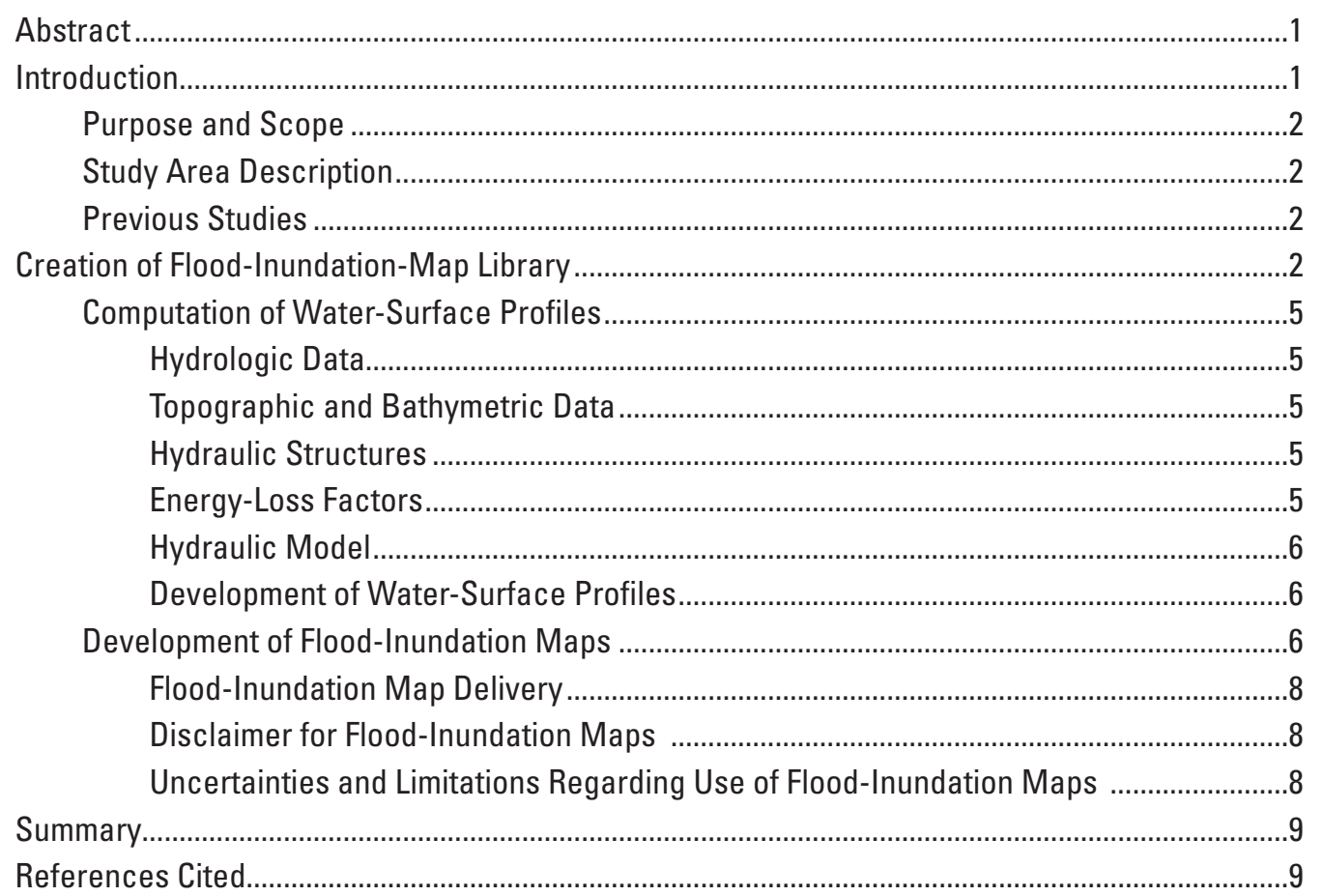




\section{Figures}

1. Map showing location of study reach for the Tippecanoe River near Winamac, Indiana, and location of U.S. Geological Survey streamgage 03331753..

2. Map showing flood-inundation map for the Tippecanoe River at Winamac, Indiana, corresponding to a stage of 16.00 feet and an elevation of 689.79 feet (NAVD 88) at the U.S. Geological Survey streamgage 03331753

\section{Tables}

1. Information on U.S. Geological Survey streamgage 03331753, Tippecanoe River at Winamac, Indiana

2. Peak discharge and observed and simulated water-surface elevations for 1-percent annual exceedance probability for Tippecanoe River at Winamac, Indiana, station 03331753.

3. Measured water-surface elevations at U.S. Geological Survey streamgage 03331753, Tippecanoe River at Winamac, Indiana, and estimated water-surface elevations output from the hydraulic model..

4. Stages and corresponding discharge estimates for simulated water-surface profiles for Tippecanoe River at Winamac, Indiana, streamgage 03331753. 


\section{Conversion Factors}

Inch/Pound to SI

\begin{tabular}{lcl}
\hline \multicolumn{1}{c}{ Multiply } & By & \multicolumn{1}{c}{ To obtain } \\
\hline foot $(\mathrm{ft})$ & Length & meter $(\mathrm{m})$ \\
mile (mi) & 0.3048 & kilometer $(\mathrm{km})$ \\
\hline & 1.609 & \\
\hline square mile $\left(\mathrm{mi}^{2}\right)$ & Area & square kilometer $\left(\mathrm{km}^{2}\right)$ \\
\hline & 2.590 & \\
\hline cubic foot per second $\left(\mathrm{ft}^{3} / \mathrm{s}\right)$ & Flow rate & cubic meter per second $\left(\mathrm{m}^{3} / \mathrm{s}\right)$ \\
\hline
\end{tabular}

Vertical coordinate information is referenced to (1) stage, the height above an arbitrary datum established at a streamgage, and (2) elevation, the height above the North American Vertical Datum of 1988 (NAVD 88).

Horizontal coordinate information is referenced to the North American Datum of 1983 (NAD 83). 



\title{
Flood-Inundation Maps for the Tippecanoe River at Winamac, Indiana
}

\author{
By Chad D. Menke and Aubrey R. Bunch
}

\section{Abstract}

Digital flood-inundation maps for a 6.2 mile reach of the Tippecanoe River at Winamac, Indiana (Ind.), were created by the U.S. Geological Survey (USGS) in cooperation with the Indiana Office of Community and Rural Affairs. The floodinundation maps, which can be accessed through the USGS Flood Inundation Mapping Science Web site at http://water. usgs.gov/osw/flood_inundation/, depict estimates of the areal extent and depth of flooding corresponding to selected water levels (stages) at the USGS streamgage 03331753, Tippecanoe River at Winamac, Ind. Current conditions for estimating near-real-time areas of inundation using USGS streamgage information may be obtained on the Internet from the USGS National Water Information System at http://waterdata.usgs. gov/in/nwis/uv?site_no $=03331753$. In addition, information has been provided by the USGS to the National Weather Service (NWS) for incorporation into their Advanced Hydrologic Prediction Service (AHPS) flood warning system (http:// water.weather.gov/ahps/). The NWS AHPS forecasts flood hydrographs at many sites that are often collocated with USGS streamgages, including the Tippecanoe River at Winamac, Ind. NWS AHPS forecast peak-stage information may be used in conjunction with the maps developed in this study to show predicted areas of flood inundation and forecasts of flood hydrographs at this site.

For this study, flood profiles were computed for the Tippecanoe River reach by means of a one-dimensional stepbackwater model. The hydraulic model was calibrated by using the most current stage-discharge relations at the Tippecanoe River streamgage, in combination with the current (2014) Federal Emergency Management Agency flood-insurance study for Pulaski County. The calibrated hydraulic model was then used to determine nine water-surface profiles for flood stages at 1-foot intervals referenced to the streamgage datum and ranging from bankfull to the highest stage of the current stage-discharge rating curve. The 1-percent annual exceedance probability (AEP) flood stage (flood with recurrence intervals within 100 years) has not been determined yet for this streamgage location. The rating has not been developed for the 1-percent AEP because the streamgage dates to only 2001. The simulated water-surface profiles were then used with a geographic information system (GIS) digital elevation model (DEM, derived from Light Detection and Ranging [lidar]) in order to delineate the area flooded at each water level. The availability of these maps, along with Internet information regarding current stage from the USGS streamgage 03331753, Tippecanoe River at Winamac, Ind., and forecast stream stages from the NWS AHPS, provides emergency management personnel and residents with information that is critical for flood response activities such as evacuations and road closures, as well as for post-flood recovery efforts.

\section{Introduction}

The town of Winamac in Pulaski County, Indiana, is a small community with an estimated population of 2,490 (U.S. Bureau of the Census, 2010). The Tippecanoe River, which flows south through the east side of the town, has severely flooded numerous times in the past. Peak flows have been recorded since August 2001 at the U.S. Geological Survey (USGS) streamgage 03331753, Tippecanoe River at Winamac, Ind. The largest recorded flood occurred when the river rose to 15.72 feet (ft) (gage datum $673.79 \mathrm{ft}$, North American Vertical Datum of 1988 [NAVD 88]) on March 14, 2009, with a discharge of 8,690 cubic feet per second $\left(\mathrm{ft}^{3} / \mathrm{s}\right)$. The most recent flooding occurred in 2011, 2013, and 2014.

Prior to this study, emergency responders in Pulaski County relied on several information sources (all of which are available on the Internet) to make decisions on how to best alert the public and mitigate flood damages. One source is the preliminary Federal Emergency Management Agency (FEMA) flood insurance study (FIS) for Pulaski County, which includes the town of Winamac, dated May 5, 2014 (Federal Emergency Management Agency, 2014). A second source of information is the USGS streamgage 03331753, Tippecanoe River at Winamac (http://waterdata.usgs.gov/in/nwis/ current/?type=flow), from which current and historical water levels (stage) can be obtained. A third source of flood-related information is the National Weather Service (NWS) Advanced Hydrologic Prediction Service (AHPS), which displays the USGS stage data from the Winamac streamgage (http://water. weather.gov/ahps/). The NWS does not routinely issue forecasts for the Tippecanoe River streamgage at Winamac, but it does so as needed during times of high-stage flows.

Although the current stage at a USGS streamgage is particularly useful for residents in the immediate vicinity of a streamgage, it is of limited use to residents farther upstream or downstream because the water-surface elevation is not 
constant along the entire stream reach. Knowledge of a water level at a streamgage is difficult to translate into depth and areal extent of flooding at points distant from the streamgage. One way to address these informational gaps is to produce a library of flood-inundation maps that are referenced to the stages recorded at the USGS streamgage. By referring to the appropriate map, emergency responders can discern the severity of flooding (depth of water and areal extent), identify roads that are or will soon be flooded, and make plans for notification or evacuation of residents in harm's way for some distance upstream and downstream from the streamgage. In addition, the capability to visualize the potential extent of flooding has been shown to motivate residents to take precautions and heed warnings that they previously might have disregarded. During 2014, the USGS, in cooperation with the Indiana Office of Community and Rural Affairs, conducted a project to produce a library of flood-inundation maps for the Tippecanoe River at Winamac, Ind.

\section{Purpose and Scope}

The purpose of this report is to describe the development of a series of estimated flood-inundation maps for the Tippecanoe River at Winamac, Ind. The maps and other flood information are available on the USGS Flood Inundation Mapping Science Web site (http://water.usgs.gov/osw/flood_ inundation/) and the NWS AHPS Web site. Internet users can select estimated inundation maps that correspond to flood stages at USGS streamgage 03331753 and the NWS AHPS forecast peak stage.

The scope of the study for hydraulic modeling was limited to the Tippecanoe River reach extending about 2.0 miles (mi) upstream from USGS streamgage 03331753 at the State Road 14 Bridge (east 13th Street) to about 4.2 mi downstream from the streamgage at State Highway Route 35 (fig. 1). The maps cover a range of stages from 8 to 16 feet ( $\mathrm{ft}$ ), gage datum. The $8 \mathrm{ft}$ stage is approximately bankfull and is defined by the NWS as the "action stage" or that stage which, when reached by a rising stream, requires the NWS or a partner to take some type of mitigation action in preparation for possible significant hydrologic activity. The $16 \mathrm{ft}$ stage is the highest rated stage at the streamgage.

\section{Study Area Description}

The drainage area of the Tippecanoe River is about 941 square miles $\left(\mathrm{mi}^{2}\right)$ at the upstream end of the modeled reach, $942 \mathrm{mi}^{2}$ at USGS streamgage 03331753 (table 1), Tippecanoe River at Winamac, Ind., and about $950 \mathrm{mi}^{2}$ at the downstream extent of the study reach (USGS, 2013a). Because the drainage area changes by only 0.9 percent throughout the reach, no significant tributaries to the Tippecanoe River are present in the modeled reach. The headwaters originate at Big Lake (not shown) in Noble County, and the stream flows generally in a southwesterly direction.
The modeled study reach is approximately $6.2 \mathrm{mi}$ long, has an average top-of-bank channel width of about $250 \mathrm{ft}$, and has an average channel slope of about 0.97 feet per mile. The flood-inundation mapping area includes the Town of Winamac. The main channel within the study reach is traversed by three roadways and one abandoned railroad. Most of the land contiguous to the study reach is either agricultural or natural area. The flood plain within the Town of Winamac is dominated by residential or recreational development.

\section{Previous Studies}

The current FIS for Pulaski County (Federal Emergency Management Agency, 2014) is a compilation of earlier community FISs, including those for the City of Winamac (Federal Emergency Management Agency, 2014) and the unincorporated areas of Pulaski County (Federal Emergency Management Agency, 2014), as well as detailed studies of selected known flood-hazard areas. In 2014, the current version (2014) of the FIS was revised to include redelineation of effective flood hazard information, conversion of incorporated and unincorporated areas of Pulaski County to a countywide format, and a correction of the data to the NAVD 88 (Federal Emergency Management Agency, 2014). The 1980s hydraulic models for the Tippecanoe River at Winamac are the basis for the data presented in the current (2014) FIS. The FIS presents only an estimate of the peak discharge with a 1-percent annual exceedance probability (AEP, flood with recurrence interval within 100 years) for the upstream start of the reach, which also represents the peak discharge at USGS streamgage, Tippecanoe River at Winamac, at the Washington Street bridge. Peak discharge and surface-water elevations are presented in table 2 for the 1-percent AEP.

\section{Creation of Flood-Inundation-Map Library}

The USGS has standardized the procedures for creating flood-inundation maps for flood-prone communities (U.S. Geological Survey, 2013b) so that the process followed and products produced are similar regardless of which USGS office is responsible for the work. Tasks specific to construction of the maps in this report were (1) compilation of flow data from streamgage 03331753 , (2) collection of topographic data and geometric data (for structures/bridges) throughout the study reach, (3) estimation of energy-loss factors (roughness coefficients) in the stream channel and flood plain, (4) computation of water-surface profiles using the U.S. Army Corps of Engineers' HEC-RAS computer program (U.S. Army Corps of Engineers, 2010), (5) production of estimated flood-inundation maps at various stream stages using the U.S. Army Corps of Engineers' HEC-GeoRAS computer program (U.S. Army Corps of Engineers, 2009) and a Geographic Information 


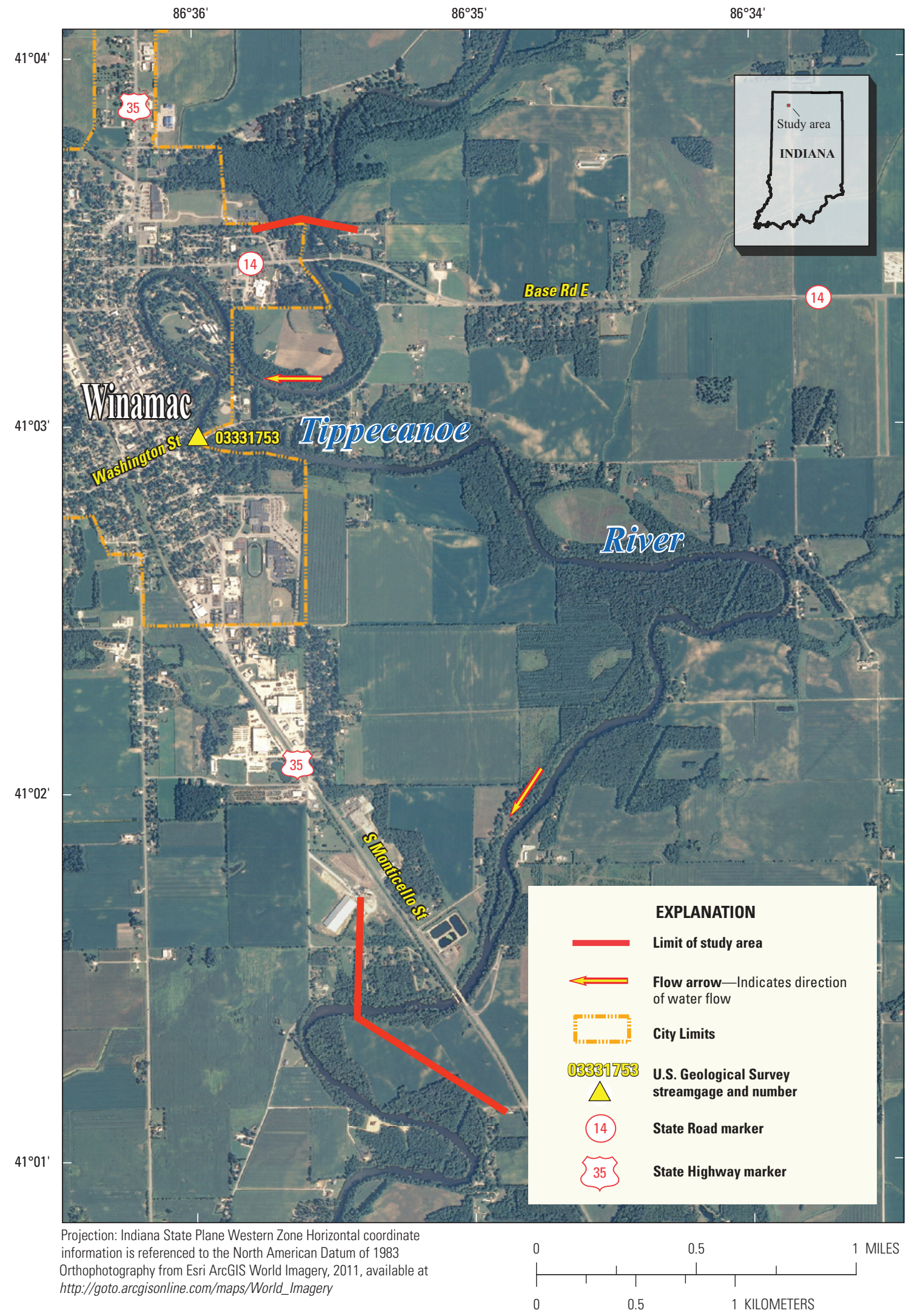

Figure 1. Location of study reach for the Tippecanoe River near Winamac, Indiana, and location of U.S. Geological Survey streamgage 03331753. 


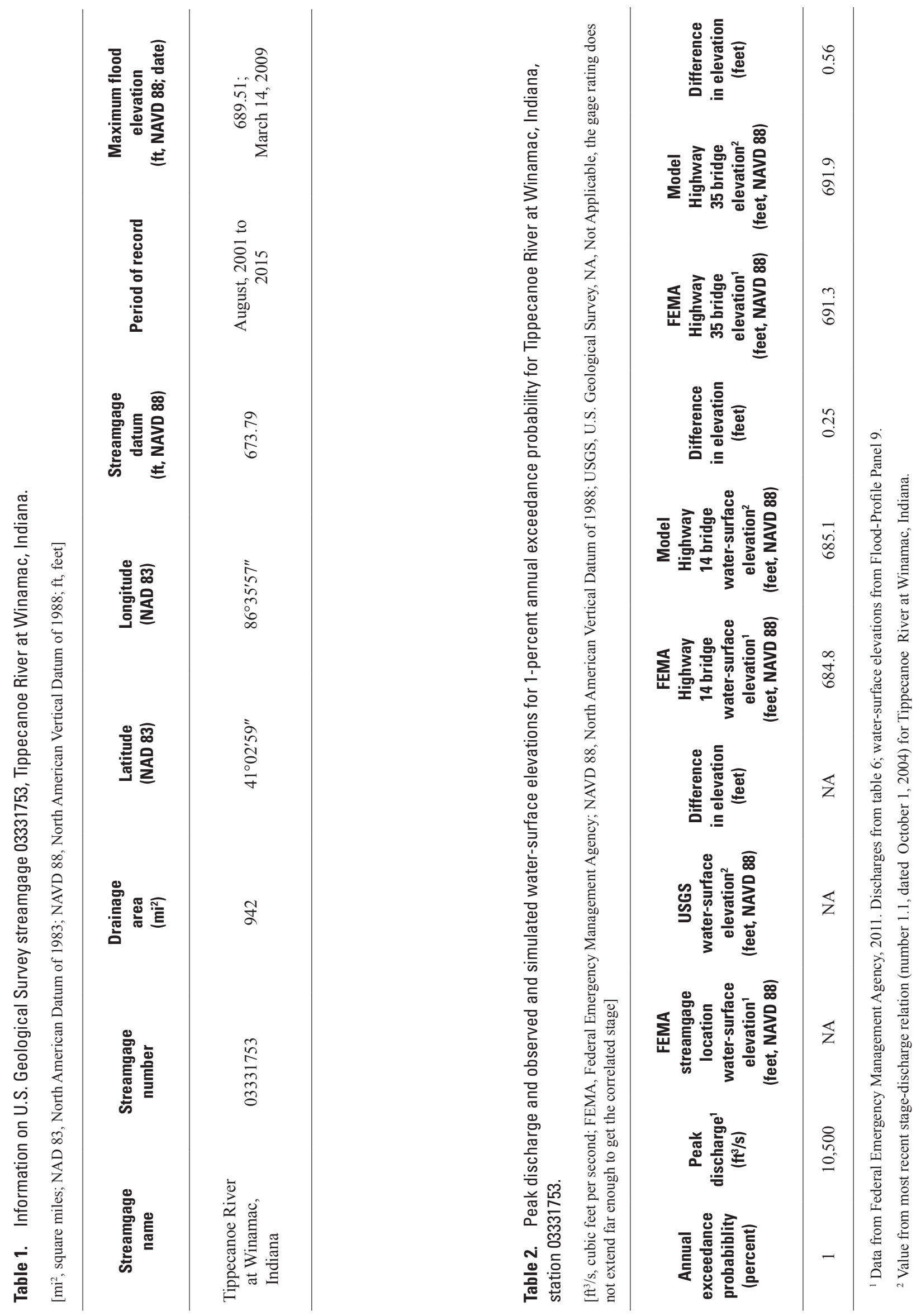


System (GIS) computer program called ArcGIS (ESRI, 2014), and (6) development of a Web interface that links to USGS real-time streamgage information and NWS AHPS forecast peak stage to facilitate the display of user-selected floodinundation maps on the Internet. Nine maps were produced for water levels referenced to the stage at USGS streamgage 03331753, Tippecanoe River at Winamac, Ind., ranging from approximately bankfull to the highest stage on the current stage-discharge rating curve.

\section{Computation of Water-Surface Profiles}

The water-surface profiles used to produce the nine flood-inundation maps in this study were simulated by using HEC-RAS, version 4.1 (U.S. Army Corps of Engineers, 2010). HEC-RAS is a one-dimensional step-backwater model for simulation of water-surface profiles with gradually varied, steady-state or unsteady-state flow computation options. The HEC-RAS analysis for this study was completed with the steady-state flow computation option.

\section{Hydrologic Data}

The study area hydrologic network consists of one streamgage (fig. 1), which has been in operation since 2001. Water level (stage) is measured continuously at this site, and continuous records of streamflow are computed. All water-surface elevations are referenced to NAVD 88. The streamgage is equipped with a satellite radio transmitter that allows data to be transmitted routinely on the Internet within an hour of collection.

Steady-flow data consist of flow regime, boundary conditions (normal depth), and peak-discharge information. The steady-flow data for the model were obtained from field measurements of streamflow at USGS streamgage 033331753 , Tippecanoe River at Winamac, Ind. All computations were based on discharge values with known stages from actual streamflow measurements or stage-discharge relations.

\section{Topographic and Bathymetric Data}

Twenty-five channel cross sections were developed from USGS surveys that were conducted in April 2012. These cross sections provide detailed channel-elevation data from below the water surface and were collected by using hydroacoustic instrumentation to measure depth. Differential Global Positioning System (DGPS) instrumentation was used to determine horizontal position in the cross section. A total of 27 synthetic cross sections were generated by use of the digital elevation model (DEM). In-channel data for all synthetic cross sections were estimated by combining Light Detection and Ranging (lidar) overbank data and bathymetric channel profiles.
Data from lidar were used to obtain digital elevation data for the portions of the cross sections that were above the water surface at the time of the surveys. The lidar data for the Tippecanoe River at Winamac, Ind., (Pulaski County lidar) were collected for the Indiana Statewide Imagery and LiDAR Program (http://gis.iu.edu/datasetInfo/statewide/in_2011.php) and were processed by Wolpert, Inc., in 2012. The lidar data have a horizontal resolution of $1.342 \mathrm{ft}$ and a vertical accuracy of $0.184 \mathrm{ft}$ at a 95 -percent confidence level, based on a root mean squared error of $1.96 \mathrm{ft}$ for the "open terrain" land-cover category. The final DEM was resampled to a grid-cell size of 10 by $10 \mathrm{ft}$ to decrease the GIS processing time and has a vertical accuracy of plus or minus $1 \mathrm{ft}$. A detailed description of the methods used to acquire and process the topographic and bathymetric data can be found in Bales and others (2007).

\section{Hydraulic Structures}

Various manmade drainage structures (bridges, culverts, and roadway embankments) in and along the Tippecanoe River affect or have the potential to affect water-surface elevations during floods along the stream. To properly account for these features in the model, structural dimensions for three bridges were measured and surveyed in the field concurrently with the stream-channel surveys. One bridge (abandoned Pennsylvania Railroad) was modeled by importing existing geometry from the 1980s hydraulic model into the current model.

\section{Energy-Loss Factors}

Hydraulic analyses require the estimation of energy losses that result from frictional resistance exerted by a channel on flow. Field observations, aerial photos, and the preliminary FIS report were used to select initial channel and flood-plain friction coefficients. These friction coefficients, commonly called Manning's roughness coefficients or Manning's $n$ values, are used in the model to account for energy loss from frictional resistance (Arcement and Schneider, 1989). As part of the calibration process, the initial $n$ values were varied by flow and adjusted until the differences between simulated and observed water-surface elevations at the streamgage and elsewhere along the study reach were minimized. The final Manning's $n$ values were set as 0.03 for the main channel and 0.05 for the overbank areas modeled in this analysis. Flow roughness factors ranging from 1.035 to 1.4 were also used during calibration at various flows for a section of the reach (river station 9644 to river station 23838), bringing $n$ values from 0.031 to 0.042 for the main channel and from 0.052 to 0.07 for the overbank areas. The flow roughness method was used to calibrate the FIS 1-percent annual exceedance profile elevation at end locations of the reach within 0.56 feet and to calibrate the stage elevations within 0.16 feet of measured water-surface elevations. 
Flood-Inundation Maps for the Tippecanoe River at Winamac, Indiana

\section{Hydraulic Model}

The HEC-RAS analysis for this study was done by using the steady-state flow computation option. Steady-state flow data consisted of flow regime, boundary conditions, and peak flows that produced water-surface elevations at the streamgage cross section that matched target water-surface elevations. These target elevations coincided with even $1 \mathrm{ft}$ increments of stage, referenced to the local gage datum. Subcritical (tranquil) flow regime was assumed for the simulations. Normal depth based on estimated average water-slope of .0001 from bathymetric survey data, was used as the reach's downstream boundary condition.

The hydraulic model was calibrated to the most current stage-discharge relation (USGS rating no. 1.1) at USGS streamgage 03331753, Tippecanoe River at Winamac, Ind. The 2014 FEMA FIS study for Pulaski County, Ind., documenting 1-percent annual exceedance probability elevations along the profile reach at the two reach-ending bridges were also used for model calibration. Model calibration was accomplished by adjusting Manning's $n$ values and roughness factors until the results of the hydraulic computations closely agreed with known flood discharge and stage values. Differences between measured and simulated water levels for measured or rated flows at USGS streamgage 03331753 were less than or equal to $0.16 \mathrm{ft}$ (table 3 ). Additional comparison was made to the flood profile from the FIS (Federal Emergency Management Agency, 2014) for the Tippecanoe River to check the model-derived water-surface elevations. The results demonstrate that the model is capable of simulating reasonable water levels over a wide range of flows in the basin. Details on techniques used in model development and calibration can be found in Bales and others (2007).

\section{Development of Water-Surface Profiles}

The calibrated hydraulic model was used to generate water-surface profiles for a total of nine stages at 1 - $\mathrm{ft}$ intervals between $8 \mathrm{ft}$ and $16 \mathrm{ft}$ as referenced to USGS streamgage 03331753, Tippecanoe River at Winamac, Ind. These stages correspond to elevations of $681.79 \mathrm{ft}$ and $689.79 \mathrm{ft}$, NAVD 88, respectively. Discharges corresponding to the various stages were obtained from the most current stage-discharge relation (rating no. 1.1) at the Tippecanoe River streamgage (table 4).

The drainage area of the Tippecanoe River is about 941 square miles $\left(\mathrm{mi}^{2}\right)$ at the upstream end of the modeled reach; $942 \mathrm{mi}^{2}$ at USGS streamgage 03331753 , Tippecanoe River at Winamac, Ind.; and about $950 \mathrm{mi}^{2}$ at the downstream extent of the study reach (USGS, 2013a). Because the drainage area changes only 0.9 percent throughout the reach, no significant contributing tributaries are present as the Tippecanoe River flows through the modeled reach. Therefore, change in flow input locations were not needed for the modeling process.
Table 3. Measured water-surface elevations at U.S. Geological Survey streamgage 03331753, Tippecanoe River at Winamac, Indiana, and estimated water-surface elevations output from the hydraulic model.

[ft, feet; NAVD 88, North American Vertical Datum of 1988]

\begin{tabular}{cccc}
\hline $\begin{array}{c}\text { Stage } \\
\text { (ft) }\end{array}$ & $\begin{array}{c}\text { Measured } \\
\text { water-surface } \\
\text { elevation } \\
\text { (ft, NAVD 88) }\end{array}$ & $\begin{array}{c}\text { Estimated } \\
\text { water-surface } \\
\text { elevation } \\
\text { (ft, NAVD 88) }\end{array}$ & $\begin{array}{c}\text { Elevation } \\
\text { difference } \\
\text { (ft) }\end{array}$ \\
\hline 8.00 & 681.79 & 681.77 & -0.02 \\
\hline 9.00 & 682.79 & 682.80 & 0.01 \\
\hline 10.00 & 683.79 & 683.79 & 0.00 \\
\hline 11.00 & 684.79 & 684.79 & 0.00 \\
\hline 12.00 & 685.79 & 685.77 & -0.02 \\
\hline 13.00 & 686.79 & 686.83 & 0.04 \\
14.00 & 687.79 & 687.77 & -0.02 \\
\hline 15.00 & 688.79 & 688.79 & 0.00 \\
\hline 16.00 & 689.79 & 689.63 & -0.16 \\
\hline
\end{tabular}

Table 4. Stages and corresponding discharge estimates for simulated water-surface profiles for Tippecanoe River at Winamac, Indiana, streamgage 03331753.

[ $\mathrm{ft}^{3} / \mathrm{s}$, cubic feet per second]

\begin{tabular}{lllllllll}
\hline \multicolumn{8}{c}{ Stage, in feet above streamgage datum } \\
\hline 8.00 & 9.00 & 10.00 & 11.00 & 12.00 & 13.00 & 14.00 & 15.00 & 16.00 \\
\hline \multicolumn{7}{c}{ Discharge (ft $3 / \mathrm{s})$} \\
\hline 2,140 & 2,756 & 3,445 & 4,207 & 5,040 & 5,930 & 6,887 & 7,911 & 9,000 \\
\hline
\end{tabular}

\section{Development of Flood-Inundation Maps}

Flood-inundation maps were created for a reach of the Tippecanoe River at Winamac, Ind. The maps were created in a GIS by combining the water-surface profiles and DEM data (an example is shown in fig. 2). Estimated flood-inundation boundaries for each simulated profile were developed using HEC-GeoRAS software (U.S. Army Corps of Engineers, 2009). HEC-GeoRAS is a set of procedures, tools, and utilities for processing geospatial data in ArcGIS using a graphical user interface (ESRI, 2014). The interface allows the preparation of geometric data for import into HEC-RAS and processes simulation results exported from HEC-RAS (U.S. Army Corps of Engineers, 2010). USGS personnel then modified the HEC-GeoRAS results to ensure a hydraulically reasonable transition of the boundary between modeled cross 


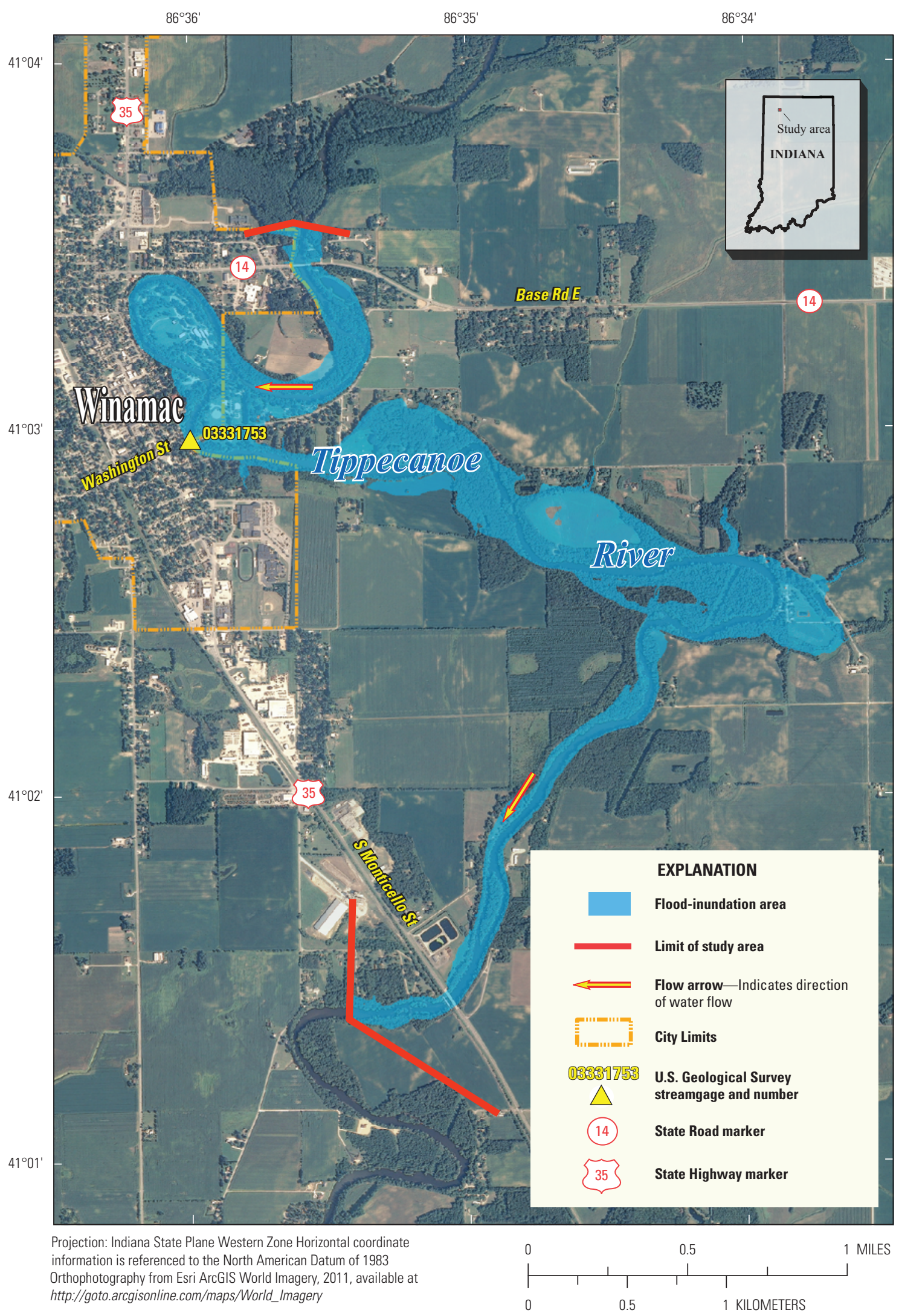

Figure 2. Flood-inundation map for the Tippecanoe River at Winamac, Indiana, corresponding to a stage of 16.00 feet and an elevation of 689.79 feet (NAVD 88) at the U.S. Geological Survey streamgage 03331753. 
Flood-Inundation Maps for the Tippecanoe River at Winamac, Indiana

sections relative to the contour data for the land surface using the method in Whitehead and Ostheimer (2009). The resulting inundation maps have a vertical accuracy of about plus or minus $1.0 \mathrm{ft}$.

Any inundated areas that were detached from the main channel were examined to identify subsurface connections with the main river, such as through culverts under roadways. Where such connections were found, the mapped inundated areas were retained in their respective flood maps; otherwise, the erroneously delineated parts of the flood extent were deleted. The flood-inundation areas are overlaid on highresolution, georeferenced aerial photographs of the study area. Bridge surfaces are displayed as inundated regardless of the actual water-surface elevation in relation to the lowest structural chord of the bridge or the bridge deck. Estimates of water depth can be obtained from the depth-grid data that are included with the presentation of the flood maps on an interactive USGS mapping application described in the following section, "Flood-Inundation Map Delivery."

\section{Flood-Inundation Map Delivery}

The flood-inundation maps from this study depict estimates of the areal extent and depth of flooding corresponding to selected water levels (stages) at the USGS streamgage 03331753, Tippecanoe River at Winamac, Ind. The current study documentation is available online at the USGS Publications Warehouse (http://dx.doi.org/10.3133/sir20155103). Also, a Flood Inundation Mapping Science Web site has been established to provide a portal at http://water.usgs.gov/osw/ flood_inundation/ to make USGS flood-inundation study information available to the public. That Web portal has a link (http://wim.usgs.gov/FIMI/FloodInundationMapper. $\mathrm{html}$ ) to a mapping application that presents map libraries and provides detailed information on flood extents and depths for selected sites. The mapping application enables the production of customized flood-inundation maps from the map library for Tippecanoe River at Winamac, Ind. At the map library site, each stream reach displayed contains further links to NWIS graphs of the current stage and streamflow at USGS streamgage 03331753 to which the inundation maps are referenced. A link also is provided to the NWS Advanced Hydrologic Prediction Service (AHPS) site (http://water.weather. gov/ahps/) so that the user can obtain applicable information on forecast peak stage. The NWS does not continuously forecast stage at this site but does so only as needed during times of high-stage flows. The estimated flood-inundation maps are displayed in sufficient detail to note the extent of flooding with respect to individual structures so that preparations for flooding and decisions for emergency response can be performed efficiently. Depending on the flood magnitude, roadways are shown as shaded (inundated and likely impassable) or not shaded (dry and passable) to facilitate emergency planning and use. Bridges are shaded - that is, shown as inundated — regardless of the flood magnitude. A shaded building should not be interpreted to mean that the structure is completely submerged, rather that bare earth surfaces in the vicinity of the building are inundated. In these instances, the water depth (as indicated in the mapping application by holding the cursor over an inundated area) near the building would be an estimate of the water level inside the structure, unless flood-proofing measures had been implemented.

\section{Disclaimer for Flood-Inundation Maps}

The flood-inundation maps should not be used for navigation, regulatory, permitting, or other legal purposes. The USGS provides these maps "as-is" for a quick reference, emergency planning tool but assumes no legal liability or responsibility resulting from the use of this information.

\section{Uncertainties and Limitations Regarding Use of Flood-Inundation Maps}

Although the flood-inundation maps represent the boundaries of inundated areas with a distinct line, some uncertainty is associated with these maps. The flood boundaries shown were estimated on the basis of water stages and streamflows at selected USGS streamgages. Water-surface elevations along the stream reaches were estimated by steady-state hydraulic modeling, assuming unobstructed flow, and using streamflows and hydrologic conditions anticipated at the USGS streamgage(s). The hydraulic model reflects the land-cover characteristics and any bridge, dam, levee, or other hydraulic structures existing as of April 2012. Unique meteorological factors (timing and distribution of precipitation) may cause actual streamflows along the modeled reach to vary from those assumed during a flood, which may lead to deviations in the water-surface elevations and inundation boundaries shown. Additional areas may be flooded due to unanticipated conditions such as changes in the streambed elevation or roughness, backwater into major tributaries along a main stem river, or backwater from localized debris or ice jams. The accuracy of the floodwater extent portrayed on these maps will vary with the accuracy of the digital elevation model used to simulate the land surface.

If this series of flood-inundation maps will be used in conjunction with National Weather Service (NWS) river forecasts, the user should be aware of additional uncertainties that may be inherent or factored into NWS forecast procedures. The NWS uses forecast models to estimate the quantity and timing of water flowing through selected stream reaches in the United States. These forecast models (1) estimate the amount of runoff generated by precipitation and snowmelt, (2) simulate the movement of floodwater as it proceeds downstream, and (3) predict the flow and stage (and water-surface elevation) for the stream at a given location (AHPS forecast point) throughout the forecast period (every 6 hours and 3 to 5 days out in many locations). For more information on AHPS forecasts, please see http://water.weather.gov/ahps/pcpn_and river_forecasting.pdf. 


\section{Summary}

Estimated flood-inundation maps were developed in cooperation with Indiana Office of Community and Rural Affairs for the Tippecanoe River at Winamac, Ind., from about $2.0 \mathrm{mi}$ upstream from USGS streamgage 03331753 at the State Road 14 Bridge to about $4.2 \mathrm{mi}$ downstream from the streamgage at State Highway Route 35 Bridge. The maps were developed by using the U.S. Army Corps of Engineers' HEC-RAS and HEC-GeoRAS programs and ESRI's ArcGIS program to compute water-surface profiles and to delineate estimated flood-inundation areas for selected stream stages. The simulated water-surface profiles were then combined with lidar data to delineate estimated flood-inundation areas as shapefile polygons and depth grids for each profile. These flood-inundation polygons were overlaid on high-resolution, georeferenced aerial photographs of the study area. The maps show estimated (shaded) flood-inundation areas in the study area for stream stages between $8 \mathrm{ft}$ and $16 \mathrm{ft}$ at the Tippecanoe River at Winamac streamgage. The flood maps are available through a mapping application that can be accessed on the USGS Flood Inundation Mapping Science Web site (http:// water.usgs.gov/osw/flood_inundation).

Interactive use of the maps on this mapping application can give users a general indication of depth of water at any point by using the mouse cursor to click within the shaded areas. These maps, in conjunction with the real-time stage data from the USGS streamgage 03331753 and National Weather Service Advanced Hydrologic Prediction Service flood-stage forecasts, will help to guide the general public in taking individual safety precautions and will provide emergency management personnel with a tool to efficiently manage emergency flood operations and postflood recovery efforts.

\section{References Cited}

Arcement, G.J., Jr., and Schneider, V.R., 1989, Guide for selecting Manning's roughness coefficients for natural channels and flood plains: U.S. Geological Survey Water-Supply Paper 2339, 38 p.
Bales, J.D., Wagner, C.R., Tighe, K.C., and Terziotti, Silvia, 2007, LiDAR-derived flood-inundation maps for realtime flood-mapping applications, Tar River Basin, North Carolina: U.S. Geological Survey Scientific Investigations Report 2007-5032, 42 p.

ESRI, 2014, ArcGIS, accessed November 18, 2014, at http:// www.esri.com/software/arcgis/.

Federal Emergency Management Agency, May 5, 2014, Flood Insurance Study, Pulaski County, Indiana, and incorporated areas: Washington D.C., Flood Insurance Study Number 18131CV000A, 19p.

U.S. Bureau of Census, 2010, State population datasetsPopulation, population change and estimated components of population change: April 1, 2006 to July 1, 2010: U.S. Bureau of Census.

U.S. Army Corps of Engineers (USACE), Hydrologic Engineering Center, 2009, HEC-GeoRAS, GIS tools for support of HEC-RAS using ArcGIS, user's manual [variously paged], accessed November 18, 2014 at http://www.hec. usace.army.mil/software/hec-ras/hec-georas_downloads. html.

U.S. Army Corps of Engineers (USACE), Hydrologic Engineering Center, 2010, HEC-RAS river analysis systemHydraulic reference manual, version 4.1 [variously paged], accessed November 18, 2014 at http://www.hec.usace.army. mil/software/hec-ras/hecras-download.html.

U.S. Geological Survey (USGS), 2013a, StreamStats for Indiana streams, available at http://streamstats.usgs.gov/indiana. html.

U.S. Geological Survey (USGS), 2013b, USGS Flood Inundation Mapping Science: U.S. Geological Survey, accessed November 10, 2014, at http://water.usgs.gov/osw/flood inundation.

Whitehead, M.T., and Ostheimer, C.J., 2009, Development of a flood-warning system and flood-inundation mapping for the Blanchard River in Findlay, Ohio: U.S. Geological Survey Scientific Investigations Report 2008-5234, 9 p., 11 pl. 
Publication services provided by the U.S. Geological Survey Science Publishing Network Columbus Publishing Service Center West Trenton Publishing Service Center For more information concerning the research in this report contact the

Director, Indiana Water Science Center

U.S. Geological Survey

5957 Lakeside Boulevard

Indianapolis, IN 46278-1996

http://in.water.usgs.gov/ 
